\title{
ПОРІВНЯЛЬНИЙ АНАЛІЗ ЗМІСТУ ДІЯЛЬНОСТІ ЛОГОПЕДА З ДІЯЛЬНІСТЮ СУМІЖНИХ ФАХІВЦІВ
}

\author{
кандидат педагогічних наук, доиент Цимбал-Слатвінська Світлана
}

\author{
Украӥна, Умань, Уманський державний педагогічний \\ університет імені Павла Тичини \\ ORCID ID 0000-0002-2732-5716
}

DOI: https://doi.org/10.31435/rsglobal_wos/31082019/6657

\begin{tabular}{|c|c|}
\hline ARTICLE INFO & ABSTRACT \\
\hline $\begin{array}{l}\text { Received: } 27 \text { June } 2019 \\
\text { Accepted: } 18 \text { August } 2019 \\
\text { Published: } 31 \text { August } 2019\end{array}$ & $\begin{array}{l}\text { The article compares the content and features of speech therapist } \\
\text { activity against the activity of related specialists. The general functions } \\
\text { of speech therapist professional activity and related specialists }\end{array}$ \\
\hline $\begin{array}{l}\text { KEYWORDS } \\
\text { speech therapist activity, } \\
\text { excellent features, } \\
\text { general functions, } \\
\text { comparison. }\end{array}$ & $\begin{array}{l}\text { pedagogical, educational, and organizational-managerial. Distinctive } \\
\text { features of the speech therapist are psychoprophylactic, counseling, } \\
\text { correction-developmental, diagnostic-analytical, mastering which } \\
\text { characterizes one as a competent specialist in the support of children } \\
\text { with speech impairment and ones readiness for professional activity. }\end{array}$ \\
\hline
\end{tabular}

Citation: Svitlana Tsymbal-Slatvinska. (2019) Comparative Analysis of the Content of Speech Therapist Activity Against Related Professionals Activities. International Academy Journal Web of Scholar. 8(38), Vol.2. doi: 10.31435/rsglobal_wos/31082019/6657

Copyright: (C) 2019 Svitlana Tsymbal-Slatvinska. This is an open-access article distributed under the terms of the Creative Commons Attribution License (CC BY). The use, distribution or reproduction in other forums is permitted, provided the original author(s) or licensor are credited and that the original publication in this journal is cited, in accordance with accepted academic practice. No use, distribution or reproduction is permitted which does not comply with these terms.

Вступ. Неухильне зростання кількості дітей, які мають різні форми відхилень у мовленнєвому розвитку, актуалізує потребу у кваліфікованих логопедах.

Особливість професії логопеда полягає в тому, що за своєю суттю вона орієнтована на допомогу іншим людям. Тому вибір саме такої професії передбачає чітко виражену гуманістичну орієнтацію (орієнтацію на людину 3 iі проблемами). Гуманізація ставлення суспільства до осіб з проблемами в розвитку та інтеграція їх в усі сфери соціального життя вносить суттєві корективи в їхню професійну діяльність [1, с. 41].

Діяльність логопеда має один серйозний аспект. Як вузький фахівець він належить до об'єднання дефектологів, головним обов'язком яких $\epsilon$, перш за все, виявлення та надання допомоги дітям з різними аномаліями у психофізичному розвитку. Така соціальна позиція дефектологів грунтується на розумінні головної ролі системи корекційно-освітніх заходів для психічного розвитку дітей, які мають вади в сенсорній (порушення зору, слуху), моторній (порушення опорно-рухового апарату), мовленнєвій та інтелектуальній сферах, і активізації їхнії компенсаторних можливостей. Ефективність педагогічного впливу істотно залежить від забезпечення таких умов. По-перше, корекція вад розвитку і формування основних умінь i навичок чіткіше відбувається в оптимальні (сенситивні) для їх виникнення вікові періоди. Подруге, система заходів повинна бути адекватна можливостям тієї або іншої дитини і враховувати своєрідність властивих їй особливостей пізнавальної діяльності [8, с. 33].

Головна відмінність корекційної діяльності полягає в тому, що спектр установ, де може працювати логопед, надзвичайно широкий. Він включає не тільки різні типи й види освітніх організацій, а й організацій охорони здоров'я, соціального захисту, психолого-медико-педагогічні консультації. I майбутній логопед, який отримав диплом, повинен добре орієнтуватися в цій величезній професійній сфері. Істотна відмінність спеціальності «логопед» від інших педагогічних спеціальностей полягає ще в тому, що бакалавр-логопед у процесі навчання 
повинен бути підготовлений до роботи з різними категоріями дітей (за віком: діти дошкільного, шкільного віку, дорослі; за діагнозом: дизартрія, ринолалія, дисфонія, полтерн, тахілалія, браділалія, 3 порушеннями лексико-граматичної будови, 3 порушеннями фонематичного сприйняття, алалія, заїкання, дисграфія, дислексія, афазія). Якщо студент-дефектолог знає, що він буде працювати 3 розумово відсталими дітьми, тифлопедагог - зі сліпими та слабозорими, сурдопедагог - із глухими дітьми і слабочуючими, студент факультету дошкільної освіти - 3 дошкільнятами, то майбутній логопед може в подальшому працювати з усіма представленими видами порушень, 3 дітьми-інвалідами та сиротами, а також у загальноосвітній школі (на шкільному логопункті), дошкільній організації (логопедичній групі), 3 підлітками тощо. Необхідно відзначити, що робота логопеда з різними категоріями дітей неоднакова, вона має чітко виражену специфіку в різних корекційних освітніх організаціях і службах.

Отже, свою діяльність майбутній логопед може здійснювати у дошкільних закладах (логопедичні, компенсаторні та інклюзивні групи), закладах загальної середньої освіти, спеціальних, навчально і соціально реабілітаційних центрах, логопунктах при поліклініках, ПМПК (нині - ІРЦ),

3 метою розкриття особливостей, властивих тільки професійної діяльності логопедів, проведемо порівняльний аналіз їхньої праці та праці інших фахівців за видами професійної діяльності, на основі досліджень діяльності спеціального психолога (О. Дружиловська [2]), учителя-логопеда (Е. Жукатинська [3]), вихователя (Ю. Пінчук [7]), соціального педагога (Н. Пахомова [6]), лікаря (М. Малофєєв [4]). Науковці вважають, що в педагогічних спеціальностях представлені навчально-виховна, соціально-педагогічна, науково-методична, організаційно-управлінська діяльність. За логопедичними спеціальностями до перерахованих додаються корекційно-розвивальна, діагностично-аналітична, консультативна, психопрофілактична діяльності, які складають основний профіль логопеда.

Результати дослідження. Процес підготовки майбутнього логопеда багато в чому схожий 3 процесом підготовки лікаря. Розкриваючи інтегрований підхід у розвитку й диференційований підхід до освіти аномально розвинених дітей, М. Малофєєв указує, що організація адекватних умов навчання може забезпечуватися комплексною участю фахівців різного профілю: клініцистів, нейрофізіологів, психологів, педагогів у побудові освітнього маршруту для цих дітей [4]. Відповідно він стверджує такі положення:

- клініцисти і нейрофізіологи за допомогою клінічних і параклінічних досліджень покликані виявляти первинні порушення в розвитку дитини й визначати можливість i необхідність корекції засобами медицини;

- психологи покликані виявляти і кваліфікувати викликані первинними вторинні порушення у психічному розвитку дитини і визначати можливість і необхідність їх корекції шляхом власне психологічної допомоги;

- логопеди спільно з педагогами повинні виявляти особливі освітні потреби дитини, зумовлені вторинними порушеннями в розвитку;

- педагоги, володіючи спеціальними знаннями, визначають шляхи, методи й засоби задоволення особливих освітніх потреб дитини у процесі спеціального навчання. таблиці 1.

Особливості та порівняльний аналіз змісту діяльності логопеда й лікаря показано у

Таблиця 1. Порівняльний аналіз змісту діяльності логопеда і лікаря

\begin{tabular}{|c|c|}
\hline Діяльність логопеда & Діяльність лікаря \\
\hline 1 & 2 \\
\hline \multicolumn{2}{|c|}{ Реєстрація скарг } \\
\hline $\begin{array}{l}\text { на неуспішність за програмою розвитку } \\
\text { мовлення }\end{array}$ & на стан здоров'я хворого \\
\hline \multicolumn{2}{|c|}{ Діагностика виявлення } \\
\hline $\begin{array}{l}\text { актуального рівня, сформованості знань, вищих } \\
\text { психічних функцій, особистості дитини } 3 \\
\text { вадами мовлення за допомогою відповідних } \\
\text { методів і патопсихологічних методик вивчення }\end{array}$ & $\begin{array}{l}\text { реального рівня стану здоров'я за допомогою } \\
\text { відповідних методів і методик обстеження }\end{array}$ \\
\hline
\end{tabular}


Продовження таблиці 1.

\begin{tabular}{|c|c|}
\hline 1 & 2 \\
\hline \multicolumn{2}{|c|}{ Якісно-кількісний аналіз результатів } \\
\hline $\begin{array}{l}\text { вивчення властивостей, якостей особистості } \\
\text { дитини } 3 \text { порушеннями мовлення }\end{array}$ & клінічна діагностика \\
\hline \multicolumn{2}{|c|}{ Діагноз (або висновок) } \\
\hline $\begin{array}{l}\text { висновок про реальний рівень сформованості } \\
\text { (знань, умінь, навичок, стану вищих } \\
\text { психічних функцій, властивостей, якостей } \\
\text { особистості тощо) }\end{array}$ & $\begin{array}{l}\text { встановлення медичного (клінічного) діагнозу } \\
\text { на основі аналізу результатів клінічної } \\
\text { діагностики }\end{array}$ \\
\hline \multicolumn{2}{|c|}{ Корекційний етап спрямований на } \\
\hline $\begin{array}{l}\text { розробку корекційно розвивальної програми } \\
3 \text { формування правильного мовлення за } \\
\text { результатами вивчення експериментальних } \\
\text { даних }\end{array}$ & $\begin{array}{l}\text { складання програми медичної корекції } 3 \\
\text { нормалізації стану хворого } \\
\text { медикаментозного лікування) }\end{array}$ \\
\hline \multicolumn{2}{|c|}{ Повторна діагностика з метою } \\
\hline $\begin{array}{l}\text { виявлення ефективності реалізації психолого- } \\
\text { педагогічної корекції }\end{array}$ & $\begin{array}{l}\text { перевірки ефективності реалізації медичної } \\
\text { корекції (після лікування) }\end{array}$ \\
\hline \multicolumn{2}{|c|}{ Аналіз результатів, порівняння даних } \\
\hline експериментальне дослідження & медикаментозне лікування \\
\hline \multicolumn{2}{|c|}{ Діагноз (або висновок) } \\
\hline $\begin{array}{l}\text { психолого-педагогічний висновок про } \\
\text { навченість дитини } 3 \text { порушеннями мовлення } \\
\text { (вказуються тенденції до поліпшення, } \\
\text { погіршення або без змін стану, якості) }\end{array}$ & $\begin{array}{lccc}\text { медичний } & \text { (клінічний) } & \text { діагно3 хворого } \\
\text { (вказуються } & \text { тенденції } & \text { до поліпшення, } \\
\text { погіршення або відсутності змін у здоров 'í) }\end{array}$ \\
\hline \multicolumn{2}{|c|}{ Рекомендації } \\
\hline $\begin{array}{l}\text { логопеда (за необхідності направлення на } \\
\text { психолого-медико-педагогічний консиліум, } \\
\text { консультацію тощо) }\end{array}$ & 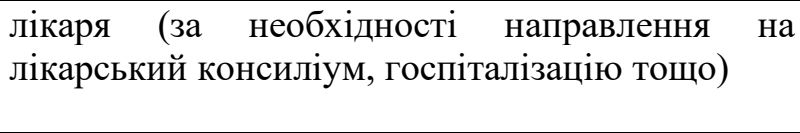 \\
\hline
\end{tabular}

Аналіз таблиці доводить, що логопед і лікар у своїй діяльності з виконання функціональних обов'язків проходять практично одні й ті самі етапи і в результаті виходять на висновок (діагноз).

Обов'язковість тісної співпраці майбутнього логопеда $з$ усіма фахівцями, задіяними в корекційний процес, передбачає володіння прийомами професійного спілкування 3 колегами для досягнення максимально позитивного результату у справі корекції відхилень у мовленнєвому розвитку дитини [3, с. 61].

Діяльність логопеда пов'язана з усіма фахівцями, які працюють в установі, кожен фахівець, орієнтуючись на вирішення питань у сфері своєї компетентності вносить відповідне розуміння цілісної картини визначення стану й розвитку дитини, а також прогноз іiі можливостей у плані подальшого виховання й навчання. У постановці нозологічного діагнозу вирішальна роль належить лікареві (психіатру, неврологові, педіатру та ін.). Кваліфікація мовленнєвого розвитку покладається на логопеда, який спільно з дефектологом визначає адекватні можливості дитини, форму навчання, а також тип освітнього закладу. Спеціальна ситуація розвитку, середовище, в якому перебуває дитина поза освітнім закладом, особливості соціального статусу оцінюються соціальним педагогом. Спеціальний психолог встановлює рівень та особливості актуального психічного розвитку дитини: інтелектуального, особливостей емоційно-вольової сфери, особистісних характеристик, особливостей міжособистісних взаємодій 3 однолітками, батьками та іншими дорослими. Спеціальний психолог оцінює, виходячи 3 цілісної картини стану й розвитку дитини, можливості оволодіння дитиною відповідних програм розвитку й навчання.

Сферою професійної діяльності вихователя дошкільних закладів $\epsilon$ освіта і виховання, логопедів - освіта дітей 3 вадами мовлення. Об'єктом професійної діяльності вихователя дошкільних закладів є освітні системи, логопеда - корекційно-освітні, реабілітаційні, соціальноадаптаційні, загальноосвітні системи. Логопед і вихователь доповнюють один одного і вирішують специфічні завдання в розвитку мовленнєвої діяльності дітей. Перш за все, слід відзначити той факт, що логопед, перш за все, здійснює корекційну функцію у вирішенні цієї проблеми. 
Вихователь свої зусилля спрямовує найбільше на розвиток мовленнєвої діяльності дітей. Логопед працює індивідуально з кожною дитиною, три рази на тиждень по 25-35 хвилин, вихователь спілкується з колективом дітей цілий день. Вихователь повинен знати основні напрями корекційної програми, вікові та індивідуальні особливості формування мовлення дошкільнят, розуміти особливості звукової та лексико-граматичної сторін мовлення і враховувати мовленнєві можливості кожної дитини у процесі навчально-виховної роботи. Робота вихователя з розвитку мовлення в більшості випадків випереджає логопедичну: це підготовка дітей до сприйняття матеріалу на майбутніх логопедичних заняттях, забезпечення пізнавальної і мотиваційної бази для формування мовленнєвих знань і вмінь. В інших випадках вихователь зосереджує свою увагу на закріпленні результатів, досягнутих дітьми на логопедичних заняттях. У завдання вихователя також входить повсякденне спостереження за станом мовленнєвої діяльності дітей на кожному періоді корекційного процесу, контроль за правильним використанням поставлених або виправлених логопедом звуків, засвоєних граматичних форм тощо.

Загальними функціями професійної діяльності логопеда та вихователя дошкільних закладів за діяльностями $є$ :

- науково-методична (виконують науково-методичну роботу, беруть участь у роботі науково-методичних об'єднань; аналізують професійну діяльність колег; проводять самоаналіз власної діяльності; займаються самоосвітою і підвищенням своєї кваліфікації);

- культурно-просвітницька (займаються формуванням загальної культури дітей; сприяють реалізації їхніх творчих здібностей);

- соціально-педагогічна (встановлюють контакт із батьками дітей, надають їм допомогу в сімейному вихованні, в соціалізації дітей; проводять профорієнтаційну роботу;

- навчально-виховна (застосовують сучасні науково обгрунтовані й найбільш адекватні прийоми, методи й засоби навчання; використовують спеціальні методики навчання з урахуванням специфіки контингенту дітей, технічні засоби навчання, інформаційні та комп'ютерні технології; застосовують засоби оцінювання результатів навчання; займаються вихованням дітей, формуванням у них духовних, моральних цінностей i патріотичних переконань на основі індивідуального підходу; застосовують сучасні педагогічні технології в навчанні й вихованні дітей 3 вадами мови в умовах інтегрованого, включеного навчання; організовують і проводять різні заходи; здійснюють особистісно орієнтований підхід до освіти та розвитку дітей; проводять роботу 3 навчання й виховання дітей з урахуванням корекції відхилень у розвитку);

- організаційно-управлінська (ведуть документацію; займаються організацією самостійної діяльності дітей; беруть участь у самоврядуванні; виконують функції вихователя).

Відмінними особливостями роботи логопеда є:

- у психопрофілактичній діяльності: залучення дітей 3 порушеннями мовлення до соціально-економічного життя суспільства у специфічних обставинах діяльності; створення умов для максимально можливого залучення дітей з порушеннями мовлення в усі сфери соціально-культурного життя суспільства 3 урахуванням особливостей їхнього здоров'я; пропаганда логопедичних знань, милосердного й гуманного ставлення суспільства до дітей 3 порушеннями мовлення засобами масової інформації та іншими формами роботи; створення оптимальних умов навчання й виховання дітей з особливостями психофізичного розвитку, створення банку даних 3 метою простеження динаміки розвитку кожної дитини; надання організаційно-методичної допомоги працівникам освіти 3 питань інтегрованого та інклюзивного навчання дітей 3 порушеннями мовлення; ведення систематичної роботи 3 батьками, залучення їх до вирішення реабілітаційних та корекційних завдань навчання й виховання дітей з порушеннями мовлення; планування і проведення заходів щодо соціальної профілактики в процесі навчання й виховання; проведення профорієнтаційної роботи, виходячи 3 психофізичних особливостей дітей 3 порушеннями мовлення; проведення психопрофілактичної роботи, спрямованої на створення сприятливого психологічного клімату в освітньому закладі, сім'ї; профілактика і корекція звичок, що завдають шкоди здоров'ю, захист від несприятливого впливу соціального середовища; надання психологічної допомоги в небезпечних і надзвичайних ситуаціях природного, техногенного та соціального походження;

- в консультативній діяльності: організація і проведення консультаційної роботи 3 населенням (батьками); консультування дітей 3 порушеннями мовлення, їхніх батьків i педагогів $з$ проблем навчання, розвитку, формування соціальних компетентностей i професійного самовизначення; 
- в корекційно-розвивальній діяльності: здійснення лікувально-відновлювальної роботи; здійснення роботи, спрямованої на максимальну корекцію обмежених можливостей у розвитку мовлення дітей; забезпечення адекватного корекційно-компенсаторного впливу на розвиток дітей 3 порушеннями мовлення; вирішення завдань забезпечення спеціальними засобами навчання й соціальної реабілітації процесу навчання й виховання дітей з порушеннями мовлення; здійснення лікувально-відновлювальної роботи, спрямованої на зміцнення фізичного і психічного стану дитини; здійснення професійної діяльності, пов'язаної з відновленням мовлення в осіб після перенесених захворювань або травм, застосування сучасних методів, прийомів діагностики та реабілітації; корекційне навчання дітей і дорослих з порушеннями мовлення;

- в діагностично-аналітичній діяльності: виявлення дітей 3 порушеннями мовлення, проведення корекції їхнього розвитку; проведення поглибленого обстеження з метою визначення структурно-функціонального порушення; проведення методичної та консультаційної роботи; диференціальна діагностика для визначення типу порушень; діагностика різних сторін психічної діяльності дітей; якісно-кількісний аналіз даних діагностики та вироблення на їхній основі рекомендацій, спрямованих на підвищення ефективності навчання, виховання, корекції; проведення психолого-педагогічного обстеження з метою визначення рівня психічного розвитку, його відповідності віковим нормам, вибору програм навчання.

Психопрофілактичну й консультативну діяльності об'єднано в одну групу і позначено як «соціально-профілактична діяльність», оскільки у консультуванні суб'єктів освіти логопедові доводиться виконувати як організаційно-управлінську, так і соціально-педагогічну та профілактичну функції.

Важливою умовою діяльності логопеда $\epsilon$ вміння взаємодіяти 3 вищеназваними учасниками корекції мовлення у дітей, а також створення доброзичливого, емоційнопозитивного мікроклімату в групі. Ці основні напрями корекційної роботи 3 дітьми з вадами мови показані у таблиці 2.

Таблиця 2. Учасники та основні напрями корекційної роботи 3 дітьми 3 порушенням мовлення

\begin{tabular}{|c|c|c|c|c|}
\hline Напрям роботи & Логопед & Психолог & Вихователь & Батьки \\
\hline 1 & 2 & 3 & 4 & 5 \\
\hline $\begin{array}{c}\text { Підвищення } \\
\text { мовленнєвих } \\
\text { умінь і } \\
\text { мовленнєвої } \\
\text { активності } \\
\text { дітей в різних } \\
\text { видах } \\
\text { комунікативної } \\
\text { взаємодії }\end{array}$ & $\begin{array}{c}\text { Розвиток } \\
\text { діалогічного } \\
\text { мовлення через } \\
\text { спільне } \\
\text { розповідання й } \\
\text { обігрування } \\
\text { знайомих казок і } \\
\text { сюжетів } 3 \\
\text { використанням } \\
\text { іграшок і серії } \\
\text { картин }\end{array}$ & $\begin{array}{c}\text { Тренінгові } \\
\text { вправи. } \\
\text { Ігри, що } \\
\text { розвивають } \\
\text { комунікативні } \\
\text { навички дітей. } \\
\text { Заняття, що } \\
\text { формують } \\
\text { навички } \\
\text { спілкування у } \\
\text { дітей. Вправи на } \\
\text { збагачення } \\
\text { досвіду взаємодї } \\
\text { дитини з } \\
\text { дорослими і } \\
\text { однолітками }\end{array}$ & $\begin{array}{c}\text { Інсценування } \\
\text { казок, читання } \\
\text { творів художньої } \\
\text { літератури, } \\
\text { віршів, сюжетно- } \\
\text { рольові ігри. } \\
\text { Активізація і } \\
\text { підвищення } \\
\text { мотивації дітей у } \\
\text { групі до } \\
\text { спонукання } \\
\text { спілкування з } \\
\text { однолітками й } \\
\text { дорослими }\end{array}$ & $\begin{array}{c}\text { Активізація і } \\
\text { підвищення } \\
\text { мотивації } \\
\text { дитини в сім'ї, } \\
\text { спрямована на } \\
\text { розвиток } \\
\text { комунікативних } \\
\text { умінь та навичок }\end{array}$ \\
\hline $\begin{array}{c}\text { Своєчасне } \\
\text { запобігання і } \\
\text { виявлення } \\
\text { мовленнєвих та } \\
\text { комунікативних } \\
\text { труднощів }\end{array}$ & $\begin{array}{c}\text { Діагностика } \\
\text { рівня } \\
\text { мовленнєвого } \\
\text { розвитку дітей. } \\
\text { Просвітництво } \\
\text { педагогів і } \\
\text { батьків (буклети, } \\
\text { пам'ятки, } \\
\text { стендова } \\
\text { інформація) }\end{array}$ & $\begin{array}{c}\text { Діагностика } \\
\text { стану } \\
\text { комунікативних } \\
\text { навичок. } \\
\text { Просвітництво } \\
\text { педагогів і } \\
\text { батьків (буклети, } \\
\text { пам’ятки, } \\
\text { стендова } \\
\text { інформація) }\end{array}$ & $\begin{array}{c}\text { Семінари- } \\
\text { практикуми, } \\
\text { консультації } 3 \\
\text { мовленнєвого } \\
\text { комунікативного } \\
\text { розвитку дітей }\end{array}$ & $\begin{array}{c}\text { Аналіз суб’єкт- } \\
\text { суб'єктних } \\
\text { стосунків у } \\
\text { родині як умови } \\
\text { профілактики } \\
\text { мовленнєвих і } \\
\text { комунікативних } \\
\text { порушень через } \\
\text { анкетування } \\
\text { батьків, } \\
\text { індивідуальні } \\
\text { консультації }\end{array}$ \\
\hline
\end{tabular}


Продовження таблиці 2.

\begin{tabular}{|c|c|c|c|c|}
\hline 1 & 2 & 3 & 4 & 5 \\
\hline $\begin{array}{c}\text { Корекція і } \\
\text { подолання } \\
\text { мовленнєвих і } \\
\text { комунікативних } \\
\text { порушень }\end{array}$ & $\begin{array}{c}\text { Розвиток у } \\
\text { дитини } \\
\text { фонетико- } \\
\text { фонематичних } \\
\text { процесів; } \\
\text { зв’язного } \\
\text { мовлення; } \\
\text { семантики } \\
\text { (активного і } \\
\text { пасивного } \\
\text { словника). } \\
\end{array}$ & $\begin{array}{c}\text { Формування } \\
\text { психічних } \\
\text { процесів і } \\
\text { корекція } \\
\text { пізнавальної та } \\
\text { емоційної сфери }\end{array}$ & $\begin{array}{c}\text { Взаємодія з } \\
\text { фахівцями щодо } \\
\text { виправлення } \\
\text { труднощів дітей } \\
\text { за допомогою } \\
\text { ігор, вправ, } \\
\text { спільних занять }\end{array}$ & $\begin{array}{c}\text { Спільні заняття } 3 \\
\text { педагогами. } \\
\text { Закріплення } \\
\text { отриманих знань } \\
\text { в умінь в } \\
\text { домашніх та } \\
\text { індивідуальних } \\
\text { завданнях }\end{array}$ \\
\hline $\begin{array}{c}\text { Створення } \\
\text { сприятливого } \\
\text { психологічного } \\
\text { клімату для } \\
\text { розвитку в } \\
\text { дітей } \\
\text { комунікативних } \\
\text { навичок у } \\
\text { різних } \\
\text { ситуаціях } \\
\text { спілкування в } \\
\text { дошкільних } \\
\text { освітніх } \\
\text { установах }\end{array}$ & $\begin{array}{c}\text { Підвищення } \\
\text { мотивації дитини } \\
\text { до подолання } \\
\text { мовленнєвих } \\
\text { проблем. } \\
\text { Виховання } \\
\text { шанобливого й } \\
\text { доброзичливого } \\
\text { ставлення один } \\
\text { до одного }\end{array}$ & $\begin{array}{c}\text { Розвиток почуття } \\
\text { належності до } \\
\text { групи. } \\
\text { Отримання } \\
\text { досвіду } \\
\text { позитивної } \\
\text { взаємодії. } \\
\text { Подолання } \\
\text { бар’єрів у } \\
\text { спілкуванні. } \\
\text { Розвиток довіри } \\
\text { до оточуючих } \\
\text { дітей і дорослих, } \\
\text { потреби у } \\
\text { спілкуванні і } \\
\text { взаємодії }\end{array}$ & $\begin{array}{c}\text { Запобігання } \\
\text { спробам дітей у } \\
\text { проявах } \\
\text { негативного } \\
\text { ставлення до } \\
\text { дітей з } \\
\text { мовленнєвими } \\
\text { труднощами. } \\
\text { Читання } \\
\text { художньої } \\
\text { літератури. } \\
\text { Формування } \\
\text { морально- } \\
\text { культурного } \\
\text { рівня дітей }\end{array}$ & $\begin{array}{c}\text { Участь у заходах } \\
\text { дитячого садка: } \\
\text { День відкритих } \\
\text { дверей, День } \\
\text { сім'ї, } \\
\text { відвідування й } \\
\text { активна участь у } \\
\text { святах, } \\
\text { змаганнях, } \\
\text { батьківських } \\
\text { зборах, круглих } \\
\text { столах. } \\
\text { Розвиток } \\
\text { культури } \\
\text { спілкування }\end{array}$ \\
\hline
\end{tabular}

Корекційна робота всіх фахівців у рамках психолого-медико-педагогічного супроводу будується не просто «підсумовуванням дій фахівців», а за певною схемою і в певній послідовності. Такий підхід вимагає чітких, узгоджених дій усіх фахівців відповідно до конкретної схеми роботи.

Підготовлений логопед у процесі своєї роботи впливає на сам процес освітньої діяльності, сприяє створенню необхідних спеціальних умов для навчання дітей з порушенням мовлення. Для цього він вносить корективи у власну діяльність, бере участь у перетворенні процесу загальної і спеціальної системи освіти, поліпшенні її якісних сторін, тим самим бере участь в оновленні стратегічних орієнтирів в освітній політиці.

Отже, на основі мети підготовки майбутнього логопеда визначено, що діяльність логопеда має кілька характеристик (поліфункціональність, багаторівневість, багатоаспектність, різнорівневість) і спрямована на виконання специфічних функцій (соціально-профілактичної, діагностично-аналітичної, корекційно-розвивальної), оволодіння якими характеризує його як компетентного фахівця із супроводу дітей з порушенням мовлення та його готовність до професійної діяльності.

До групи професійно значущих якостей майбутнього логопеда віднесено: педагогічну спрямованість особистості, комунікативні здібності, організаторські здібності, емпатію, креативність, рефлексію, професійні знання. До особистісних: особистісні особливості, сенсорно-перцептивні властивості, особливості мислення та пам'яті, моторні властивості: хороша дикція, виразне мовлення; здатність до співпереживання, здатність чітко, лаконічно формулювати повідомлення; вміння зберігати активність і працездатність в умовах стомлення, що розвивається; швидкість точність маніпуляцій; витривалість до тривалих фізичних навантажень; високий рівень фізичної підготовленості (сила, спритність, координація рухів).

Професійно важливі особистісні якості завжди є соціально значущими, більше того, ці якості значимі для особистості логопеда. 3 цього випливає, що значущі якості особистості майбутнього логопеда набувають характеру основної умови формування його готовності до професійної діяльності. 
Висновки. На основі порівняльного аналізу змісту та особливостей діяльності логопеда із діяльністю суміжних фахівців встановлено загальні та відмінні ознаки. Загальними функціями професійної діяльності логопеда та суміжних фахівців за діяльностями є: науковометодична, культурно-просвітницька, соціально-педагогічна, навчально-виховна, організаційно-управлінська. Відмінними особливостями роботи логопеда $\epsilon$ такі види діяльності: психопрофілактична, консультативна, корекційно-розвивальна, діагностичноаналітична, оволодіння якими характеризує його як компетентного фахівця із супроводу дітей 3 порушенням мовлення та його готовність до професійної діяльності.

\section{ЛIТЕРАТУРА}

1. Бессмертная Н. А. Организационно-педагогические условия развития профессиональной компетентности будущих логопедов сельских образовательных учреждений: дис. канд. пед. наук. Москва. 2003: 168.

2. Дружиловская О. В. Современный подход к преподаванию дисциплин медико-биологического цикла на дефектологических факультетах педагогических вузов: дис. канд. пед. наук. Москва. 2003: 210.

3. Жукатинская Е. Н. Формирование профессиональной компетентности будущего учителя-логопеда: дис. канд. пед. наук. Липецк. 2008: 226.

4. Малофеев Н. Н. Специальное образование в меняющемся мире. Европа Москва. 2009: 319.

5. Пахомова Н. Г. Стан сформованості рефлексивно-оцінної складової інтегративної професійної підготовки майбутніх логопедів. Актуальні питання корекційної освіти. 2015. (5): 218-227.

6. Пінчук Ю. В. Система професійної компетентності вчителя-логопеда: дис. ... канд. пед. наук. Київ. 2005: 220.

7. Стахова Л. Л. Проектирование методической системы развития профессиональной компетентности учителя-логопеда дошкольного образовательного учреждения в условиях профессиональной среды: дис. канд. пед. наук. Тамбов. 2010: 195. 